\title{
Adsorbsi lon Logam Cu (II) Menggunakan Biomassa Daun Genjer (Limnocharis flava)
}

\section{[Adsorption of $\mathrm{Cu}$ (II) lons by Biomass of Genjer Leaves (Limnocharis flava)]}

\author{
Helni Febriani*, Dwi Juli Puspitasari, Ruslan, Husain Sosidi \\ Jurusan Kimia, Fakultas MIPA, Universitas Tadulako, Palu \\ J. Soekarno Hatta Km.9, Kampus Bumi Tadulako Tondo Palu, Telp. 0451-422611
}

\begin{abstract}
The adsorption of $\mathrm{Cu}$ (II) ions by Genjer (Limnocharis flava) biomass has been carried out. This research aims to determine the optimum $\mathrm{pH}$ of the plant and the contact time between the metal ion $\mathrm{Cu}$ (II) with the plant that produces the highest absorption, as well as knowing the best adsorbent mass for absorption between $\mathrm{Cu}$ (II) metal ions and genjer plants. The study used a completely randomized design (CRD) with variables of $\mathrm{pH}$, contact time, and adsorbent mass. The testing of the absorption of the Genjer leaves biomass against $\mathrm{Cu}$ (II) was carried out with Atomic Adsorption Spectrophotometric (AAS). The results showed that the optimum absorption produced was $83.34 \%$ at pH 4 , and $91.54 \%$ with the highest contact time of 30 minutes, and $82.04 \%$ with an adsorbent mass of $1 \mathrm{gram}$.
\end{abstract}

Keywords: Limnocharis flava, pH, contact time, adsorbent mass, adsorption, Cu (II) ion

Abstrak. Telah dilakukan adsorpsi ion Cu (II) dengan menggunakan biomassa daun Genjer (limnocharis flava). Penelitian ini bertujuan untuk mengetahui $\mathrm{pH}$ optimum dari tumbuhan genjer dan waktu kontak antara ion logam $\mathrm{Cu}$ (II) dengan tumbuhan genjer yang menghasilkan penyerapan tertinggi, serta mengetahui massa adsorben terbaik untuk penyerapan antara ion logam $\mathrm{Cu}$ (II) dengan tumbuhan genjer. Penelitian menggunakan rancangan acak lengkap (RAL) dengan variabel $\mathrm{pH}$, waktu kontak, dan massa adsorben. Pengujian daya serap genjer terhadap ion $\mathrm{Cu}$ (II) dilakukan dengan Spektrofotometer Serapan Atom (SSA). Hasil penelitian menunjukkan bahwa penyerapan optimum yang dihasilkan sebesar $83,34 \%$ yaitu pada $\mathrm{pH} 4$, dan $91,54 \%$ dengan waktu kontak tertinggi 30 menit, serta $82,04 \%$ dengan massa adsorben yaitu 1 gram.

Kata Kunci: Tumbuhan genjer, pH, waktu kontak, massa adsorben, Adsorbsi, ion Cu (II)

Diterima: 20 Oktober 2019, Disetujui 20 Agustus 2021

Sitasi: Febriani, H., Puspitasari, D J., Ruslan., dan Sosidi, S. (2021). Adsorbsi Ion Logam Cu (II) Menggunakan Biomassa Daun Genjer (Limnocharis flava). KOVALEN: Jurnal Riset Kimia, 7(2): 131-136.

\section{LATAR BELAKANG}

Tembaga termasuk salah satu jenis logam berat yang dapat terakumulasi dalam tubuh manusia melalui konsumsi hewan yang telah terpapar logam tembaga dalam jumlah besar, seperti ikan. Kadar logam tembaga pada tubuh

\footnotetext{
* Corresponding author

E-mail: febrianihelni632@amail.com
}

manusia dalam jumlah banyak dapat menyebabkan keracunan (Widowati, 2008).

Limbah logam berat seperti tembaga yang seringkali mencemari lingkungan memerlukan penanganan atau pengolahan tertentu. Cara pengolahan limbah logam berat dapat dilakukan secara kimia, biologi atau fisika. Pemisahan logam berat dari lingkungan, 
seperti perairan banyak menggunakan cara kimia, yaitu dengan penambahan bahan-bahan kimia tertentu sampai terbentuknya endapan pada $\mathrm{pH}$ tinggi. Akan tetapi, cara ini sangat mahal dan dapat menyebabkan pencemaran sekunder baru. Sementara itu, penanganan limbah logam berat secara fisika, yaitu metode adsorpsi yang umumnya menggunakan karbon aktif ataupun membran. Cara ini juga membutuhkan biaya yang besar, sehingga perlu alternatif baru. Pemisahan limbah logam yang lebih murah dan aman bagi lingkungan dapt dilakukan dengan menggunakan biomassa sebagai adsorben (Rahmi \& Sajidah, 2017; Volesky \& Holan, 1995).

Biomassa adalah zat-zat organik dari maphluk hidup baik hewan maupun tumbuhan. Senyawa yang menyusun biomassa adalah makromolekul, seperti selulosa, lignin, dan hemiselulosa (Nawawi et al., 2018). Biomassa dari tanaman merupakan alternatif yang paling murah untuk digunakan sebagai adsorben. Salah satu jenis tanaman yang belum pernah dipergunakan sebagai adsorben ion logam berat tembaga, yaitu tumbuhan genjer. Hasanah (2020) menyatakan bahwa tanaman genjer dapat berfungsi juga sebagai fitoremediasi logam Cu dengan nilai akumulasi dapat mencapai 95,83\%. Genjer (Limnocharis flava) termasuk tanaman liar yang tumbuh subur pada daerah yang tergenang air atau basah, seperti tepi sungai, tanah gembur, lapisan lumpur, dan persawahan (Rusydi, 2010). Bagian daun dari tanaman genjer memiliki kandungan selulosa yang dominan sehingga sangat potensial dimanfaatkan sebagai adsorben yang murah.

Pada proses adsorpsi logam terdapat beberapa hal yang penting diperhatikan, yaitu kecepatan adsorpsi, kinetika adsorpsi, dan kualitas bahan yang diadsorpsi. Pada penelitian sebelumnya kemampuan daya serap tumbuhan genjer terhadap logam berat besi (Fe) dan mangan (Mn) telah dilakukan yang menunjukkan bahwa tanaman genjer mampu menyerap logam Fe hingga 63,99 \% dan logam Mn 63,21 \% (Priyanti \& Yunita, 2013). Lelifajri (2010) telah melakukan proses adsorpsi ion logam $\mathrm{Cu}$ (II) menggunakan lignin dari biomassa serbuk kayu gergaji pada $\mathrm{pH}$ 6, waktu kontak 30 menit, dan konsentrasi adsorbat ion $\mathrm{Cu} 20 \mathrm{mg} / \mathrm{L}$ dengan efisiensi penyerapan ion Cu (II) 99,3 \%. Sementara itu, Arman \& Nisma (2010) menggunakan metode spektrofotometri serapan atom untuk melihat penyerapan logam berat oleh tanaman eceng gondok dan genjer yang membuktikan bahwa kedua tanaman tersebut dapat menurunkan kadar logam berat di dalam air karenakan adanya biomaterial seperti protein yang dapat mengakumulasi logam berat, seperti $\mathrm{Pb}$ (II). Tujuan pemanfaatan daun genjer sebagai biomassa adalah untuk memaksimalkan manfaat dari tanaman genjer dan menghasilkan produk yang berdaya guna dan ramah lingkungan.

\section{METODE PENELITIAN}

\section{Bahan dan Peralatan}

Bahan yang digunakan meliputi daun genjer dari Desa Sidoan Kabupaten Parigi Moutong, $\mathrm{CuSO}_{4}$, larutan $\mathrm{HCl} 0,1 \mathrm{M}, \mathrm{NaOH}$, $\mathrm{HNO}_{3}$ 0,1 $\mathrm{M}$ dan akuades. Alat yang digunakan yaitu Spektrofotometer Serapan Atom (SSA), $\mathrm{pH}$ meter, blender, gunting, desikator, oven, neraca analitik dan ayakan 100 mesh.

\section{Prosedur Penelitian}

\section{Preparasi sampel}

Daun genjer dipisahkan dari akar dan batangnya, kemudian dicuci bersih, kemudian 
dikering anginkan selama 3 hari. Daun genjer kering dihaluskan dengan blender kemudian diayak pada ukuran 100 mesh.

\section{Proses aktivasi tepung daun genjer}

Tepung daun genjer ditimbang sebanyak $100 \mathrm{~g}$, kemudian direndam dalam larutan asam nitrat $\left(\mathrm{HNO}_{3}\right)$ 0,1 $\mathrm{M}$ selama 3 jam. Sampel hasil peremdaman disaring menggunakan Buchner, kemudian dicuci dengan akuades dan dikeringkan di dalam oven selama satu hari pada suhu $50^{\circ} \mathrm{C}$.

\section{Penetuan pengaruh $\mathrm{pH}$}

Sejumlah 0,5 gram adsorben genjer dimasukkan ke dalam Erlenmeyer dan ditambahkan larutan Cu 100 ppm sebanyak $100 \mathrm{~mL}$ diatur pada $\mathrm{pH}$ yang divariasi kisaran 2 , 4, 6, dan 8 dengan penambahan $\mathrm{HCl} \mathrm{0,1} \mathrm{M}$ dan $\mathrm{NaOH}$ kemudian dilakukan pengocokan pada kecepatan 150 rpm selama 1 jam dengan menggunakan shaker, kemudian didiamkan selama 15 menit adsorben dipisahkan dengan larutan dengan cara penyaringan dengan kertas saring (modifikasi metode Adriansyah et al., 2018; Setiawan et al., 2018). Sisa logam teradsorpsi dalam larutan diukur dengan SSA.

\section{Penentuan pengaruh waktu kontak}

Ke dalam 4 buah Erlenmeyer ukuran 250 $\mathrm{mL}$ masing-masing dimasukan serbuk genjer yang diaktifkan yang diperoleh sebanyak 0,5 gram dan ditambahkan larutan Cu 100 ppm pada $\mathrm{pH}$ optimum Kemudian larutan dikocok menggunakan shaker dengan kecepatan 150 rpm dengan variasi waktu 30, 60, 90, 120 menit. Kemudian adsorben dipisahkan dari larutan dengan cara penyaringan dengan menggunakan kertas saring (modifikasi metode Adriansyah et al., 2018; Setiawan et al., 2018). Sisa logam teradsorpsi dalam larutan diukur dengan SSA.

\section{Penentuan massa adsorben optimum pada adsorpsi ion $\mathrm{Cu}$ (II)}

Larutan $\mathrm{CuSO}_{4}$ disiapkan pada 4 wadah masing-masing $100 \mathrm{~mL}$ ditambahkan adsorben dengan variasi berat 0,$5 ; 1 ; 1,5$; dan 2 gram. Kondisi $\mathrm{pH}$ diatur sesuai $\mathrm{pH}$ optimum sebelumnya, kemudian dikocok menggunakan shaker dengan kecepatan 150 rpm dan waktu kontak optimum yang telah diperoleh sebelumnya. Kemudian adsorben dipisahkan dari larutan dengan cara penyaringan dengan menggunakan kertas saring (modifikasi metode Adriansyah et al., 2018; Setiawan et al., 2018). Sisa logam teradsorbsi dalam larutan diukur dengan SSA.

\section{HASIL DAN PEMBAHASAN}

Kondisi pH Optimum Adsorpsi Ion Cu (II) oleh Biomassa Daun Genjer

Penentuan pengaruh $\mathrm{pH}$ merupakan parameter penting untuk menentukan kapasitas penyerapan yang diperoleh pada genjer terhadap ion logam dalam larutan. Penentuan derajat keasaman akan mempengaruhi muatan situs aktif yang terdapat pada permukaan adsorben yang berperan aktif dalam proses penyerapan ion logam. $\mathrm{pH}$ yang digunakan pada penelitian ini dari kondisi asam hingga sedikit basa, yaitu 2, 4, 6 dan 8 .

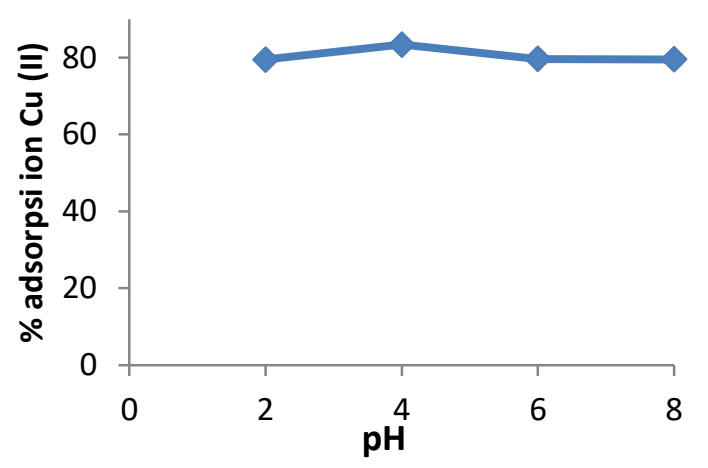

Gambar 1. Hubungan $\mathrm{pH}$ terhadap persentasi adsorpsi ion $\mathrm{Cu}$ (II) 
Peningkatan kapasitas adsorbsi ion Cu (II) mengalami kenaikan pada $\mathrm{pH} 2$ sampai $\mathrm{pH} 4$, adsorbsi tertinggi terjadi pada $\mathrm{pH} 4$, namun kapasitas mengalami penurunan kembali pada pH 6 dan pH 8 (Gambar 1). Hal ini menunjukan bahwa makin meningkatnya $\mathrm{pH}$ maka derajat keasaman makin kecil sehingga penyerapan ion logam semakin besar. Besarnya nilai $\mathrm{pH}$ larutan mempunyai pengaruh terhadap proses adsorpsi, karena $\mathrm{pH}$ akan mempengaruhi muatan permukaan adsorben dan spesi apa saja yang diserap pada saat proses adsorbsi. Menurut Dewi et al. (2015), penggunaan pH di atas 4, yaitu 5-6 akan menyebabkan penurunan penyerapan $\mathrm{Cu}(\mathrm{II})$ oleh adsorben bentonit karena pada $\mathrm{pH}$ tersebut dapat terbentuk $\mathrm{Cu}(\mathrm{OH})_{2}$. Pada $\mathrm{pH}$ di bawah 4, jumlah $\mathrm{Cu}$ yang terserap juga lebih sedikit dikarenakan adanya kompetisi dengan ion $\mathrm{H}^{+}$yang melimpah untuk dapat teradsorbsi (Benelli et al., 2013).

\section{Waktu Kontak Optimum Adsorpsi Ion Cu (II) oleh Biomassa Daun Genjer}

Pengaruh waktu adsorbsi merupakan parameter penting dalam menentukan kapasitas adsorben.

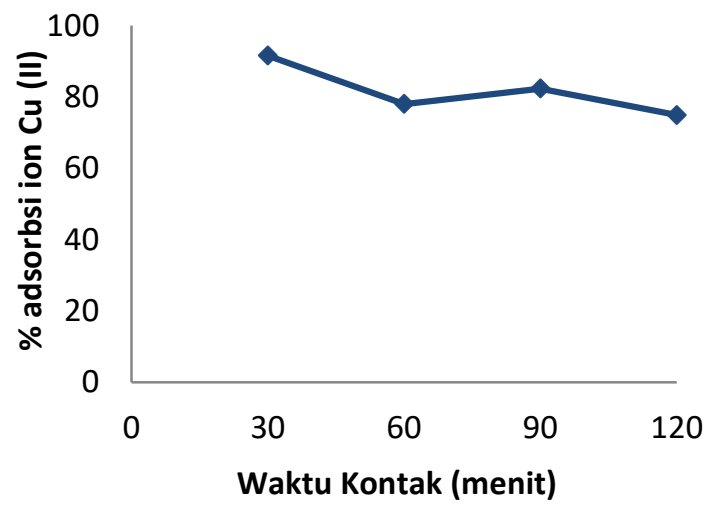

Gambar 2. Hubungan waktu kontak terhadap persentasi adsorpsi ion $\mathrm{Cu}$ (II)

Persentase adsorpsi tertinggi diperoleh pada waktu 30 menit dengan jumlah persen adsorbsi 91,54\% (Gambar 2). Mufrodi et al., (2010) menyatakan bahwa waktu kontak merupakan suatu hal yang sangat menentukan dalam proses adsorpsi dimana waktu kontak adalah lamanya waktu yang dibutuhkan untuk pengadukan antara genjer sebagai adorben dan larutan $\mathrm{Cu}$ sebagai adsorbat. Semakin lama waktu kontak maka proses adsorpsi juga akan semakin meningkat, tetapi ketika kondisi setimbang telah tercapai adsorben cenderung melepas (desorpsi) sehingga persentase adsoprsi menjadi berkurang sebagaimana yang terjadi setelah waktu 90 menit, atau dengan kata lain biosorben genjer mengalami waktu jenuh.

\section{Massa adsorben optimum pada adsorpsi ion Cu (II)}

Pengaruh jumlah adsorben merupakan parameter penting karena dapat menentukan kapasitas adsorben selama penambahan kosentrasi awal adsorbat.

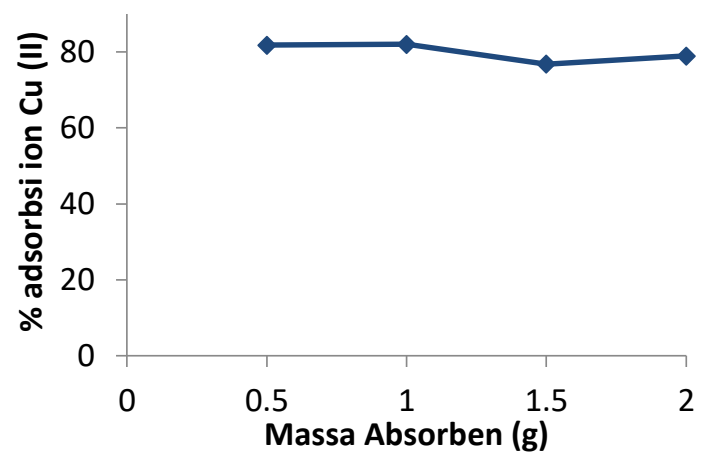

Gambar 3. Hubungan massa adsorben terhadap persentasi adsorpsi ion Cu (II)

Berat adsorben yang dilakukan dalam pengujian ini adalah 0,5; 1; 1,5 dan 2 gram. Hasil pengujian tersebut menunjukan bahwa efesiensi adsorpsi tertinggi terjadi pada berat 1 gram yaitu sebesar 82,04 \% (Gambar 3). Nilai efesiensi terendah terjadi pada saat berat adsorben 1,5 gram, yaitu sebesar 76,82 \%.

Bertambahnya berat adsorben sebanding dengan bertambahnya jumlah pertikel dan luas permukaan karbon aktif sehingga 
menyebabkan jumlah tempat mengikat ion logam bertambah dan efesiensi adsorpsinyapun meningkat (Messayu, 2009). Terjadinya penurunan efisiensi adsorpsi setalah penambahan 1 gram adsorben genjer diduga terjadi karena adanya agregasi parsial pada adsorben biomassa genjer, yaitu pembentuk sebagian agregat pada partikel adsorben ketika berlangsungnya proses pengadukan (Maruthi et al., 2013).

\section{KESIMPULAN}

Adsorpsi ion $\mathrm{Cu}$ (II) oleh biomassa daun genjer memilki kondisi optimum pada $\mathrm{pH} 4$ dengan efisiensi adsorpsi 83,34\%, sedangkan waktu kontak optimum diperoleh pada waktu kontak 30 menit dengan a efisiensi dsorpsi 91,54\%. Massa adsorben optimum pada adsorpsi ion $\mathrm{Cu}$ (II) oleh biomassa daun genjer diperoleh pada berat 1 gram dengan efisiensi adsorbsi 82,04\%.

\section{DAFTAR PUSTAKA}

Adriansyah, R., Restiasih, E. N., \& Meileza, N. (2018). Biosorpsi Ion Logam Berat Cu(II) Dan $\mathrm{Cr}(\mathrm{VI})$ Menggunakan Biosorben Kulit Kopi Terxanthasi. Alotrop, 2(2): 114-121. https://doi.org/10.33369/atp.v2i2.7478

Arman, B., \& Nisma, F. (2010). Pengaruh Umur Eceng Gondok (Eichornia crassipes) dan Genjer (Limnocharis flava) terhadap Penyerapan Logam $\mathrm{Pb}, \mathrm{Cd}$, dan $\mathrm{Cu}$ dalam Ember Perlakuan dengan Metode Spektrofotometri Serapan Atom. Jurnal Farmasains, 1(2).

Benelli, C., Borgogelli, E., Formica, M., Fusi, V., Giorgi, L., Macedi, E., Micheloni, M., Paoli, P., \& Rossi, P. (2013). Di-maltolpolyamine ligands to form heterotrinuclear metal complexes: Solid state, aqueous solution and magnetic characterization. Dalton Transactions, 42(16): 5848-5859. https://doi.org/10.1039/C3DT32130D
Dewi, P. A. I. K., Suarya, P., \& Sibarani, J. (2015). Adsorpsi lon Logam Pb2+ Dan $\mathrm{Cu}^{2+}$ Oleh Bentonit Teraktivasi Basa $(\mathrm{NaOH})$. Jurnal Kimia (Journal of Chemistry), $\quad$ 9(2): 235-242. https://doi.org/10.24843/JCHEM.2015.v 09.i02.p14

Hasanah, U. (2020). Fitoremediasi Logam Tembaga $(\mathrm{Cu})$ Oleh Tanaman Genjer (Limnocharis flava) Dari Sawah Di Daerah Malang Berdasarkan Variasi Konsentrasi Dan Waktu Pemaparan [Skrips]. UIN Maulana Malik Ibrahim, Malang.

Lelifajri, L. (2010). Adsorpsi lon Logam Cu(II) Menggunakan Lignin dari Limbah Serbuk Kayu Gergaji. Jurnal Rekayasa Kimia \& Lingkungan, 7(3): 126-129.

Maruthi, Y., Dadhich, A., Hossain, K., \& Jyothsna, A. (2013). Nirmali Seed as a Natural Biosorbent; Evaluation of its Potential for Iron (II) Removal from Steel Plant Effluents and Sewage Disinfecting Capacity. European Journal of Sustainable Development, 2(3): 77-84. https://doi.org/10.14207/ejsd.2013.v2n3 p77

Messayu, P. (2009). Limbah Arang Sekam Padi Sebagai Adsorben lon $\mathrm{Cr}$ (III) dan $\mathrm{Cr}$ (IV) [Skripsi]. Institut Pertanian Bogor, Bogor.

Mufrodi, Z., Rochmadi, S., \& Budiman, A. (2010). Effects of temperature and catalyst upon triasetin production from glycerol (byproduct biodiesel production) as octane booster. Proc. Advances in Renewable Energy Technologies Int. Conf., 130-134.

Nawawi, D. S., Carolina, A., Saskia, T., Darmawan, D., Gusvina, S. L., Wistara, N. J., Sari, R. K., \& Syafii, W. (2018). Karakteristik Kimia Biomassa untuk Energi. J. Ilmu Teknol. Kayu Tropis, 16(1): 44-51.

Priyanti, P., \& Yunita, E. (2013). UJI Kemampuan Daya Serap Tumbuhan Genjer (Limnocharis flava) Terhadap Logam Berat Besi (Fe) Dan Mangan (Mn). Prosiding SEMIRATA 2013, 1, Article 
https://jurnal.fmipa.unila.ac.id/semirata/a rticle/view/684

Rahmi, R., \& Sajidah, S. (2017). Pemanfaatan Adsorben Alami (Biosorben) Untuk Mengurangi Kadar Timbal $(\mathrm{Pb})$ Dalam Limbah Cair. Prosiding Biotik, 5(1). https://jurnal.arraniry.ac.id/index.php/PBiotik/article/vie w/2162

Rusydi, R. (2010). Analisis Mikroskopis dan Komponen Bioaktif Tanaman Genjer (Limnocharis flava) dari Kelurahan Situ Gede Bogor [Skripsi], Institut Pertanian Bogor].

http://repository.ipb.ac.id/handle/123456 $789 / 62847$

Setiawan, E., Nurhayati, A. P. D., de Voogd, N. J., Dewi, A. T., Alivy, A., Kartikasari, L., \& Subagio, I. (2018). Toxicity test of mangrove epibiont sponges in Tampora Situbondo using brine shrimp lethality test (BSLT). AIP Conference Proceedings, 2002(1), 020017. https://doi.org/10.1063/1.5050113

Volesky, \& Holan, Z. (1995). Biosortion of heavy metals. Biotechnology Progress, 11: 235-250.

Widowati, W. (2008). Efek Toksik Logam Pencegahan dan Penanggulangan Pencemaran. Penerbit Andi, Yogyakarta. 